\title{
Production of Biogas from Bagasse: Effect of Cow Dung to Bagasse Feed Ratio, Media Solution pH and Digester's Moisture Content on Biogas Volume and Methane Yield
}

\author{
Malunga Sthembiso, Isa Yusuf Makarfi* \\ Chemical Engineering Department, Durban University of Technology, Durban, South Africa \\ *YusufI@dut.ac.za
}

\begin{abstract}
Anaerobic digestion experiments were conducted to investigate feasibility of biogas production from bagasse and cow dung. Design-Expert software was used for design of experiment and optimization process. Twelve experiments using $500 \mathrm{ml}$ glass bottle s digesters were conducted at temperature of $35{ }^{\circ} \mathrm{C}$ and hydraulic time of 14 days. Biogas volume was measured daily, and composition was analyzed at the end of experiment. Digester's performance was evaluated in terms of biogas volume and methane yield produced. The objective of this work was to investigate the effect of cow dung to bagasse feed ratio, digester's moisture content and media solution $\mathrm{pH}$ on biogas volume and methane yield. The results showed that high media solution $\mathrm{pH}$ and low digester's moisture content favors high biogas and methane yield. The optimum biogas volume and methane yield were found to be $305.87 \mathrm{ml}$ and methane yield of $28.75 \mathrm{ml} / \mathrm{gVS}$ respectively at digester's moisture content of $80.00 \%$, media solution $\mathrm{pH}$ of $8.00,4.64 \mathrm{~g}$ of cow dung and 5.36 $\mathrm{g}$ of bagasse.
\end{abstract}

Key words: Biogas, Bagasse, Moisture, Methane, Sugarcane,

\section{INTRODUCTION}

Sugar manufacturing industries produce bagasse which is used as fuel for steam boilers to generate power [1]. Bagasse is fibrous residue left after milling of sugarcane [2]. It is estimated that about $3000 \mathrm{~kg}$ of wet bagasse is produced when $10000 \mathrm{~kg}$ of sugarcane is crushed [3].Moisture content of bagasse is between 40 to $50 \%$ [2, 4]. Caloric value of bagasse as fuel varies due to varying composition of sugarcane plant from which bagasse was extracted from [4]. High gaseous emissions $\left(\mathrm{SO}_{2} \mathrm{CO}\right.$ and $\left.\mathrm{NO}_{\mathrm{X}}\right)$ which are emitted by bagasse fed boilers are of great concern [5]. Environmental and public health problems are likely to worsen in the future should sugarcane industries continue to burn bagasse for energy requirements. Bagasse like any other biomass can be converted into environmentally friendly biogas [6].
Biogas is a mixture of different gasses produced by breakdown of organic matter in the absence of oxygen in the process is called anaerobic digestion [7].Anaerobic digestion (AD)is a series of biological processes in which microorganisms break down biodegradable material in the absence of oxygen $[8,9]$. The main product of AD process is biogas, which is composed mainly of methane and carbon dioxide [10-12]. Although biogas cannot replace global energy dependence on fossils fuels but can complement other renewables to reduce dependence on fossils fuels.

The availability of biomass for biogas for commercial biogas production is of great concern without disrupting food safety because farming of energy crops is likely to compete with food production. Flavin and Lenssen [13] stated "if the contribution of biomass to the word energy economy is to grow, technological innovations will be needed, so that biomass can be converted to usable energy in ways that are more efficient, less polluting and at least as economical as today's practices."

The aim of this work was to determine feasibility of production of biogas from sugarcane bagasse and cow dung.

\section{MATERIALS AND METHOD}

\subsection{Raw materials and initial characterisation}

Substrates which were utilised in this research were sugarcane bagasse and cow dung. They were collected locally, cleaned and dried to remove excess moisture. Dried bagasse and cow dung were milled by using electric blender and sieved with $350 \mu \mathrm{m}$ screen. The undersize were used for experimentation. Inoculum was collected from sewage works anaerobic digesters at Durban Municipal waste water treatment plant primary and was stored at $4{ }^{\circ} \mathrm{C}$ to avoid spontaneous fermentation.

Standard procedure was used to determine moisture content (X), total solids (TS) and volatile solids(TS) [14]. Table 1 presents the results of initial characterisation of cow dung and bagasse. 
Malunga Sthembiso et al., International Journal of Emerging Trends in Engineering Research, 8(7), July 2020, 3898 - 3908

Table 1: Initial characterisation of cow dung and sugarcane baggasse

\begin{tabular}{|l|l|l|}
\hline Substrates & Cow dung & Bagasse \\
\hline VS(\%) & 75.00 & 78.00 \\
\hline TS(\%) & 54.00 & 97.00 \\
\hline Moisture (\%) & 46.00 & 3.00 \\
\hline
\end{tabular}

\subsection{Media solution preparation}

Media solution was prepared by dissolving required amount of $\mathrm{KH}_{2} \mathrm{PO}_{4}$ and $\mathrm{Na}_{2} \mathrm{CO}_{3}$ into distilled water. Phosphoric acid was used to adjust the $\mathrm{pH}$ of media solution to $\mathrm{pH}$ of 4.00 and 8.00 .

\section{EXPERIMENTAL DESIGN}

Design- Expert software offers designs that combine process factors and mixture components. In this work, Design-Expert's Combined (User-Defined) option was used for design of experiment and analysis. Quadratic model was used for mixture components and linear models was used for process factors. Quadratic models are traditionally used for mixture components [15]. Linear model for process factors was predicted as there were two levels (high and low) which were considered and it is permitted according to Montgomety [16]. Table 2 represents Design-Expert software input variables which were used for DOE. Mixture components were cow dung $\left(\mathrm{X}_{1}\right)$ and sugarcane biomass $\left(\mathrm{X}_{2}\right)$. Process factors were media solution $\mathrm{pH}\left(\mathrm{Z}_{1}\right)$ and moisture content $\left(\mathrm{Z}_{2}\right)$.

Table 2: Design-Expert input variables used for design of experiment

\begin{tabular}{cccc}
\hline \multirow{2}{*}{ Parameter } & \multirow{2}{*}{ Variables } & \multicolumn{2}{c}{ Levels } \\
\cline { 3 - 4 } $\begin{array}{c}\text { Cow dung } \\
(\mathrm{g})\end{array}$ & $\mathrm{X}_{1}$ & 2.00 & 8.00 \\
$\begin{array}{c}\text { Sugarcane } \\
\text { residue }(\mathrm{g})\end{array}$ & $\mathrm{X}_{2}$ & 2.00 & 8.00 \\
$\begin{array}{c}\text { Media } \\
\text { solution } \mathrm{pH}\end{array}$ & $\mathrm{Z}_{1}$ & 4.00 & 8.00 \\
$\begin{array}{c}\text { Digester } \\
\text { moisture }(\%)\end{array}$ & $\mathrm{Z}_{2}$ & 80.00 & 95.00 \\
\hline
\end{tabular}

\subsection{Modelling}

Mixture components and process factors are represented by quadratic model and linear model respectively. They are represented by equations 1 and 2 . Combined mixtureprocess model is a product of mixture and process models as presented by equation 3 [17].

$$
Y(X)=\beta_{1} X_{1}+\beta_{2} X_{2}+\beta_{12} X_{1} X_{2}+\beta_{11} X_{1}^{2}+\beta_{22} X_{2}^{2} \ldots \ldots \ldots \ldots . .1
$$

$$
\begin{aligned}
& Y(Z)=\alpha_{0}+\alpha_{1} Z_{1}+\alpha_{2} Z_{2}+\alpha_{12} Z_{1} Z_{2} \ldots \ldots \ldots \ldots \ldots . .2 \\
& Y(X, Z)=Y(X) \times Y(Z) \ldots \ldots \ldots \ldots \ldots \ldots \ldots \ldots \ldots . . . \ldots \ldots \ldots \ldots \ldots \ldots
\end{aligned}
$$

Equation 4 represents combined multiplicative model for equations 1 and 2 .

$$
\begin{aligned}
& Y(X, Z)=\alpha_{0} \beta_{1} X_{1}+\alpha_{1} Z_{1} \beta_{1} X_{1}+\alpha_{2} Z_{2} \beta_{1} X_{1}+\alpha_{12} Z_{1} Z_{2} \beta_{1} X_{1}+\alpha_{0} \beta_{2} X_{2} \\
& +\alpha_{1} Z_{1} \beta_{2} X_{2}+\alpha_{2} Z_{2} \beta_{2} X_{2}+\alpha_{12} Z_{1} Z_{2} \beta_{2} X_{2}+\alpha_{0} \beta_{12} X_{1} X_{2}+\alpha_{1} Z_{1} \beta_{12} X_{1} X_{2} \\
& +\alpha_{1} Z_{1} \beta_{12} X_{1} X_{2}+\alpha_{12} Z_{1} Z_{2} \beta_{12} X_{1} X_{2}+\alpha_{0} \beta_{11} X_{1}^{2}+\alpha_{1} Z_{1} \beta_{11} X_{1}^{2} \\
& +\alpha_{2} Z_{2} \beta_{11} X_{1}^{2}+\alpha_{12} Z_{1} Z_{2} \beta_{11} X_{1}^{2}+\alpha_{0} \beta_{22} X_{2}^{2}+\alpha_{1} Z_{1} \beta_{22} X_{2}^{2} \\
& +\alpha_{2} Z_{2} \beta_{22} X_{2}^{2}+\alpha_{12} Z_{1} Z_{2} \beta_{22} X_{2}^{2} \\
&
\end{aligned}
$$

Where: Y represents methane yield or biogas volume

$$
\alpha_{0}, \alpha_{1}, \alpha_{12}, \beta_{1}, \beta_{2}, \beta_{11}, \beta_{12} \text { and } \beta_{22} \text { represent }
$$

model coefficient, $X_{1}$ and $X_{2}$ represent cow dung and bagasse respectively, $Z_{1}$ and $Z_{2}$ represent media solution $\mathrm{pH}$ and digester's moisture content respectively.

\subsection{Experimental procedure}

Sugarcane bagasse and cow dung were charged into reactor as required based on the experimental design. Experiments were conducted in a mesophilic temperature condition $\left(35^{\circ} \mathrm{C}\right)$ for 14 days. Experimental set up is shown in Figure 1. AD process temperature was controlled by using water bath set at $35{ }^{\circ} \mathrm{C}$. Biogas volume generated was measured daily using water displacement method. Biogas composition was analysed at the end of experiments by using GC.

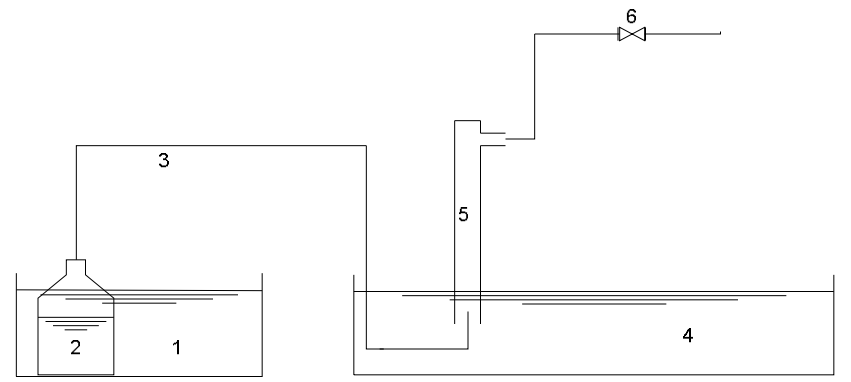

Figure 1: Schematic diagrams of anaerobic digestion: Water bath (1), 500ml Schott bottle (2), $6 \mathrm{~mm}$ ID flexible tube (3), acrylic water basin (4), glass tube with the ID of $20 \mathrm{~mm}$ with the opening at the bottom (5) and a clamp (6).

\subsection{Analytical methods}

Water displacement method was used to determine the volume of biogas generated. Measuring tape was used to measure the height of water displaced by biogas. Gas chromatography (GC) was used to analyse biogas composition. Standard $\mathrm{pH}$ meter was used to measure the $\mathrm{pH}$ of media solution. Mass of media solution and substrates were measured by using mass balance. 
Equation 5 was used to calculate the mass of media solution required to achieve required digester moisture as presented in Table 3. Calculated mass of media for each reactor is presented in Table 4.

$$
M_{s o l}=\left(\frac{1-\varphi_{s l}}{\varphi_{s l}}\right)\left(T S_{A}+T S_{B}\right)-\left[X_{A} M_{A}+X_{B} M_{B}\right]
$$

Where: $M_{\text {sol }}$ represent total amount of media solution required $(\mathrm{g}), \mathrm{M}_{\mathrm{A}}$ and $\mathrm{M}_{\mathrm{B}}$ represent mass of cow dung and bagasse respectively, $\mathrm{TS}_{\mathrm{A}}$ and $\mathrm{TS}_{\mathrm{B}}$ represent total solids of cow dung and bagasse $(\mathrm{g}), \mathrm{X}_{\mathrm{A}}$ and $\mathrm{X}_{\mathrm{B}}$ represent moisture

content of cow dung and bagasse respectively (\%), $\phi_{s l}$ represents fraction of total solid content of slurry charged into reactor.

Total VS charged into each reactor was calculated from equation 6. Results of total VS are presented in Table 3.

$$
V S_{t o t}(g)=T S_{A} V S_{A} M_{A}+T S_{B} V S_{B} M_{B}
$$

Where: $\mathrm{TS}_{\mathrm{A}}$ and $\mathrm{TS}_{\mathrm{B}}$ represent total solids of cow dung and bagasse respectively (\%), $\mathrm{M}_{\mathrm{A}}$ and $\mathrm{M}_{\mathrm{B}}$ represent initial weights of cow dung and bagasse respectively, $\mathrm{VS}_{\mathrm{A}}$ and $\mathrm{VS}_{\mathrm{B}}$ represent volatile solids for cow dung and bagasse respectively $(\%)$.

Equation 7 was used to calculate biogas volume generated. Total biogas volume generated is presented in Table 3.1.

$$
Y_{1}(m l)=\sum_{i=1}^{14} \pi r^{2} h_{i}
$$

Where: $r$ represents radius of the tube, $h_{i}$ represents height of water displaced, $Y_{1}$ represents total biogas volume at the end of 14 days, $\Pi$ is the constant which is approximated to 3.141

Equation 8 was used to calculate methane yield at the end of experiment. Results of methane yield are presented in Table 3.

$$
Y_{2}\left(m l \mathrm{CH}_{4} / g V S\right)=\frac{Y_{2}}{V S_{\text {tot }}} \times n_{\mathrm{CH}_{4}}
$$

Where: $Y_{2}$ represents methane yield, $Y_{1}$ represents total of biogas volume (ml), ${ }^{n_{\mathrm{CH}_{4}}}$ represents methane concentration
$(\%), \mathrm{VS}_{\text {tot }}$ represents total volatile solids charged into reactor (g).

\section{RESULTS AND DISCUSSION}

Biogas volume $\left(\mathrm{Y}_{1}\right)$, methane yield $\left(\mathrm{Y}_{2}\right)$, volatile solids $\left(V S_{t o t}\right)$, media solution( $\left.M_{s o l}\right)$ and methane concentration $\left(n_{\mathrm{CH}_{4}}\right)$ results are presented in Table 3.

Table 3: Experimental results of biogas volume and methane yield for cow dung and bagasse co-digestion.

Table 3 indicates that the highest biogas volume of 329.69 $\mathrm{ml}$ and methane yield of $29.52 \mathrm{ml} / \mathrm{gVS}$ were achieved from reactor 8 , which was charged with cow dung to bagasse feed ratio $\mathrm{C}$ : $\mathrm{B}$ of $5: 5$, media solution with $\mathrm{pH}$ of 8.00 and moisture content of $80.00 \%$.

The lowest biogas volume of $26.71 \mathrm{ml}$ and methane yield of $1.63 \mathrm{ml} / \mathrm{gVS}$ were achieved by reactor 12 which was charged with $\mathrm{C}$ : B feed ratio of $2: 8$, media solution with $\mathrm{pH}$ of 4.00 and moisture content of $95.00 \%$. Table 3 also reveals that the best performing reactors were charged with $\mathrm{C}$ : $\mathrm{B}$ feed ratio of 5:5 compared to reactors which were charged with C: B feed ratio of 8:2 and 2:8 when they were operated at the similar conditions.

\subsection{Models}

Biogas volume and methane yield models are represented by equation 9 and 10 respectively.

$$
\begin{aligned}
& Y_{1}=-9.9 \mathrm{X}_{1}-48.5 \mathrm{X}_{2}+42.30 \mathrm{X}_{1} \mathrm{X}_{2}+0.145 \mathrm{X}_{1} \mathrm{Z}_{2}+5.14 \mathrm{X}_{2} \mathrm{Z}_{1} \ldots \ldots . .9 \\
& +0.28 \mathrm{X}_{2} \mathrm{Z}_{2}-0.42 \mathrm{X}_{1} \mathrm{X}_{2} \mathrm{Z}_{2}
\end{aligned}
$$

$$
\begin{aligned}
& Y_{2}=-0.517 X_{1}-7.78 X_{2}+4.98 X_{1} X_{2}+0.0097 X_{1} Z_{2}+0.429 X_{2} Z_{1} \ldots .10 \\
& +0.059 X_{2} Z_{2}-0.0494 X_{1} X_{2} Z_{2}
\end{aligned}
$$

Where: $Y_{1}$ and $Y_{2}$ represents biogas volume $(\mathrm{ml})$ and methane yield ( $\mathrm{ml} / \mathrm{gVS})$ respectively.

$X_{1}$ and $X_{2}$ represent weights $(g)$ of cow dung and bagasse respectively.

$\mathrm{Z}_{1}$ and $\mathrm{Z}_{2}$ represent media solution $\mathrm{pH}$ and digester moisture content $(\%)$ respectively

\subsection{Biogas volume model}

ANOVA results for biogas volume model is presented in Table 4 shows that biogas volume model has F-value of 14.19 which implies that the model is significant. P-value of 0.0053 implies that there is $0.53 \%$ chance that F-value could occur due to noise. Coefficient of determination $\left(\mathrm{R}^{2}\right)$ indicates how close the data fits the model. $\mathrm{R}^{2}$ was found to be 0.9445 , which implies goodness of fit. Pred $R^{2}$ of 0.6966 is in reasonable agreement with the "Adj $\mathrm{R}^{2}$ of 0.8780 . A difference of less than 0.2 is acceptable [15]. Coefficient of variation (CV) is the 
measure of residual variation related to the size of the mean. High value of $\mathrm{CV}$ is the indication of the lower reliability of the experiment while lower CV means high reliability of the experiment $[16,18]$. In this work, CV was found to be $18.93 \%$ which indicates high reliability of experiment. Adequate precision measures the signal to noise ratio. Ratio greater than 4 is desirable [18]. In this current work, adequate precision was found to be 12.03 which indicate an adequate signal. Therefore, this model can be used to navigate the design space.

Table 4: ANOVA results of cow dung and bagasse codigestion experiment biogas volume model

\begin{tabular}{cccccc}
\hline Source & $\begin{array}{c}\text { Sum of } \\
\text { Squares }\end{array}$ & di & $\begin{array}{c}\text { Mean } \\
\text { Square }\end{array}$ & $\begin{array}{c}\mathbf{F} \\
\text { Value }\end{array}$ & $\begin{array}{c}\text { p-value } \\
\text { Prob > F }\end{array}$ \\
\hline Model & 72569.75 & 6 & 12094.96 & 14.19 & 0.0053 \\
Linear & 913.48 & 1 & 913.48 & 1.07 & 0.3479 \\
Mixture & & & & & \\
$\mathbf{X}_{\mathbf{1}} \mathbf{X}_{\mathbf{2}}$ & 2823.12 & 1 & 2823.12 & 3.31 & 0.1284 \\
$\mathbf{X}_{\mathbf{1}} \mathbf{Z}_{\mathbf{2}}$ & 57.02 & 1 & 57.02 & 0.067 & 0.8062 \\
$\mathbf{X}_{\mathbf{2}} \mathbf{Z}_{\mathbf{1}}$ & 39371.95 & 1 & 39371.95 & 46.21 & 0.0010 \\
$\mathbf{X}_{\mathbf{2}} \mathbf{Z}_{\mathbf{2}}$ & 202.65 & 1 & 202.65 & 0.24 & 0.6464 \\
$\mathbf{Z}_{\mathbf{1}} \mathbf{X}_{\mathbf{2}} \mathbf{Z}_{\mathbf{2}}$ & 2133.55 & 1 & 2133.55 & 2.50 & 0.1744 \\
\hline
\end{tabular}

$R^{2}=0.9445$, Adjusted $R^{2}=0.8780$, Coefficients of variation $(C V)=18.93$, Adequate precision=12.039, Standard deviation $=29.19$, Pred $R^{2}=0.6966$

\subsection{Methane yield model}

Table 5 indicates that methane yield model as presented by equation 4.5 has F-value of 8.76. P-value of 0.0154 indicates that there is $1.54 \%$ chance that F-value this large could occur due to noise. "Pred R-Squared" of 0.6236 is in reasonable agreement with the "Adj R-Squared" of 0.8088; i.e. the difference is less than 0.2. "Adeq Precision" measures the signal to noise ratio. A ratio greater than 4 is desirable. In this current work ratio of 10.069 indicates an adequate signal. This model can therefore be used to navigate the design space.

Table 5: ANOVA results for cow dung and bagasse codigestion methane yield model

\begin{tabular}{cccccc}
\hline Source & $\begin{array}{c}\text { Sum of } \\
\text { Squares }\end{array}$ & df & $\begin{array}{c}\text { Mean } \\
\text { Square }\end{array}$ & $\begin{array}{c}\mathbf{F} \\
\text { Value }\end{array}$ & $\begin{array}{c}\text { p-value } \\
\text { Prob }>\mathbf{F}\end{array}$ \\
\hline Model & 660.06 & 6 & 110.01 & 8.76 & 0.0154 \\
\hline $\begin{array}{c}\text { Linear } \\
\text { Mixture }\end{array}$ & 10.97 & 1 & 10.97 & 0.87 & 0.3929 \\
$\mathbf{X}_{\mathbf{1}} \mathbf{X}_{\mathbf{2}}$ & 39.10 & 1 & 39.10 & 3.11 & 0.1380 \\
$\mathbf{X}_{\mathbf{1}} \mathbf{Z}_{\mathbf{2}}$ & 0.25 & 1 & 0.25 & 0.020 & 0.8933 \\
$\mathbf{X}_{\mathbf{2}} \mathbf{Z}_{\mathbf{1}}$ & 274.96 & 1 & 274.96 & 21.89 & 0.0054 \\
$\mathbf{X}_{\mathbf{2}} \mathbf{Z}_{\mathbf{2}}$ & 9.19 & 1 & 9.19 & 0.73 & 0.4314 \\
$\mathbf{X}_{\mathbf{1}} \mathbf{X}_{\mathbf{2}} \mathbf{Z}_{\mathbf{2}}$ & 29.64 & 1 & 29.64 & 2.36 & 0.1852 \\
\hline
\end{tabular}

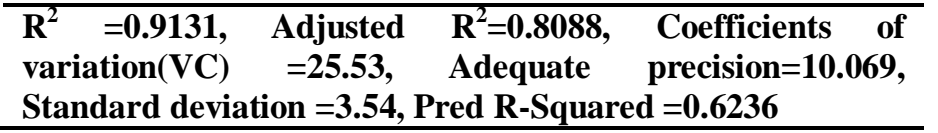

Figure 2 represents normal probability plot of biogas volume model. It can be observed that its shape is almost linear and means that data is normally distributed. Figure 3 represents predicted vs actual plot. The shape is almost straight at 45 degrees which indicates that experimental results are close to predicted.

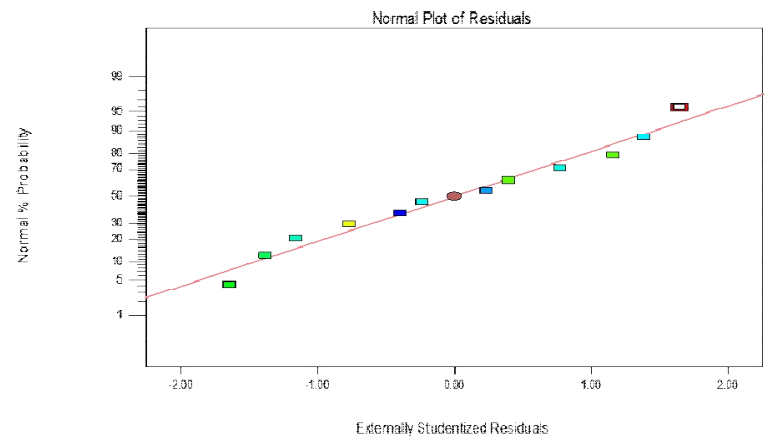

Figure 2: Normal probability vs studentized residual for bagasse and cow dung biogas volume model

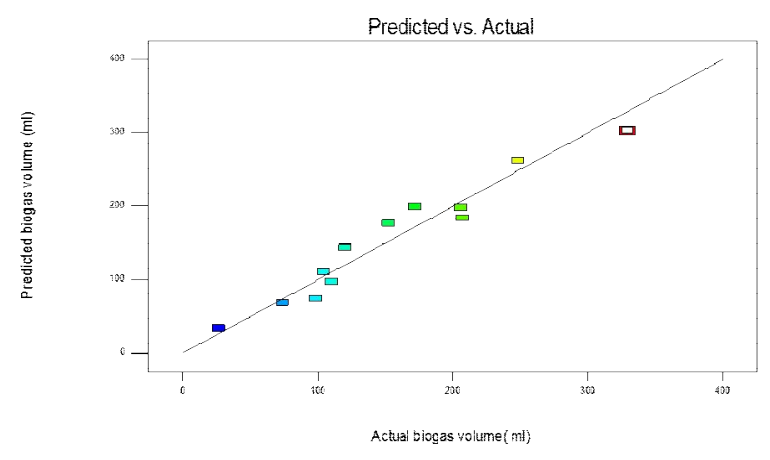

Figure 3: Normal probability vs studentized residual for bagasse and cow dung biogas volume model

Normal probability plot shape of straight line as indicated by Figure 4 indicates that data is normally distributed. Figure 5 represents predicted vs actual values plot which is a straight around 45 degrees. This is the indication of good of fit.

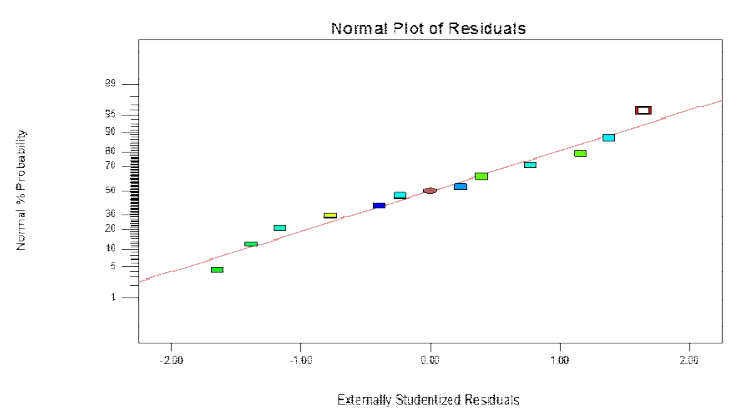

Figure 4: Normal probability plot of bagasse and cow dung model for methane yield 


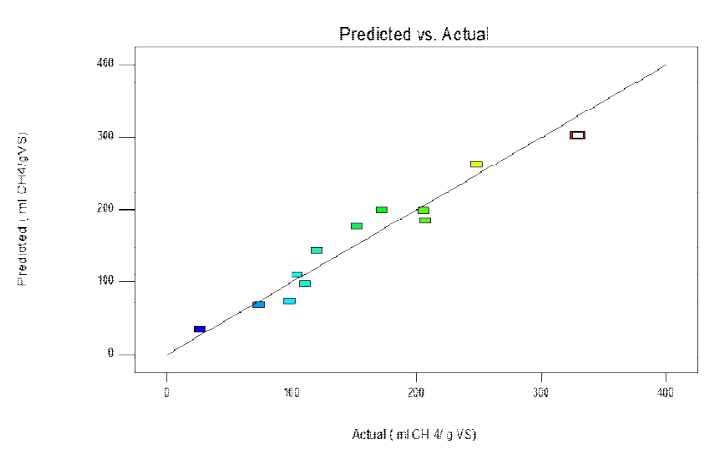

Figure 5: Predicted values versus the actual values of methane yield for cow dung ad bagasse

The effects of process variables on biogas volume and methane yield were investigated by using one variable at a time (OVAT) approach, where, comparisons of two reactors results were done. In addition to OVAT approach, graphical technique was used to analyse the effect of process variables on biogas volume and methane yield where one process variable is fixed at central position.

\subsection{The effect of media solution $\mathrm{pH}$ on biogas volume and methane yield}

Reactors 5 and 9 were charged with equal C: B feed ratio of 8:2, digester's moisture content of $95.00 \%$ and charged with media solution $\mathrm{pH}$ of 4.00 and 8.00 respectively. Table 3 shows that reactor 9 achieved higher biogas volume and methane yield of $104.34 \mathrm{ml}$ and $9.44 \mathrm{ml} / \mathrm{gVS}$ respectively compared to reactor 5 where lower biogas volume of 73.86 $\mathrm{ml}$ and $7.77 \mathrm{ml} / \mathrm{gVS}$ were achieved. In this analysis, it was observed that reactor charged with high media solution $\mathrm{pH}$ achieved higher biogas and methane yield values.

Table 3 shows that reactors 2 and 7 were charged with equal C: B feed ratio of 8:2, digester's moisture content of $95.00 \%$ and charged with media solution with $\mathrm{pH}$ of 4.00 and 8.00 respectively. Table 3 reveals that reactor 7 achieved higher biogas volume and methane yield of $207.43 \mathrm{ml}$ and $24.44 \mathrm{ml} / \mathrm{gVS}$ respectively compared to reactor 2 where biogas volume and methane yield of $120.37 \mathrm{ml}$ and 10.64 $\mathrm{ml} / \mathrm{gVS}$ were achieved. In this analysis, reactor which was charged with high $\mathrm{pH}$ (8.00) media solution achieved higher biogas volume and methane yield values.

Reactors 3 and 8 were charged with equal C: B feed ratio (5:5), operated at moisture content of $80 \%$ and charged with media solutions $\mathrm{pH}$ of 4.00 and 8.00 respectively as shown in Table 4.3. Higher values of biogas volume $(329.69 \mathrm{ml})$ and methane yield $(29.52 \mathrm{ml} / \mathrm{gVS})$ were achieved by reactor 8 compared to reactor 3 where lower biogas volume and methane yield of $172.23 \mathrm{ml}$ and $19.57 \mathrm{ml} / \mathrm{gVS}$ were achieved. In this analysis, high media solution $\mathrm{pH}$ charged reactor attained higher biogas volume and methane yield values.
Reactors 1 and 4 were charged with equal C: B feed ratio (5:5), operated digester's moisture content $(95.00 \%)$ and charged with media solution with $\mathrm{pH}$ of 8.00 and 4.00 respectively. Table 3 shows that reactor 1 achieved higher biogas volume and methane yield of $152.43 \mathrm{ml}$ and $13.65 \mathrm{ml} / \mathrm{gVS}$ respectively. Reactor 4 achieved biogas volume of $98.37 \mathrm{ml}$ and methane yield of $8.64 \mathrm{ml} / \mathrm{gVS}$. In this analysis, it can be observed that the reactor which was charged with media solution $\mathrm{pH}$ resulted to higher biogas and methane yield values.

Figures 6 and 7 represent 2-D contour graphical representation of biogas volume and methane yield models respectively at media solution fixed at central point of $\mathrm{pH}$ of 6.00 .

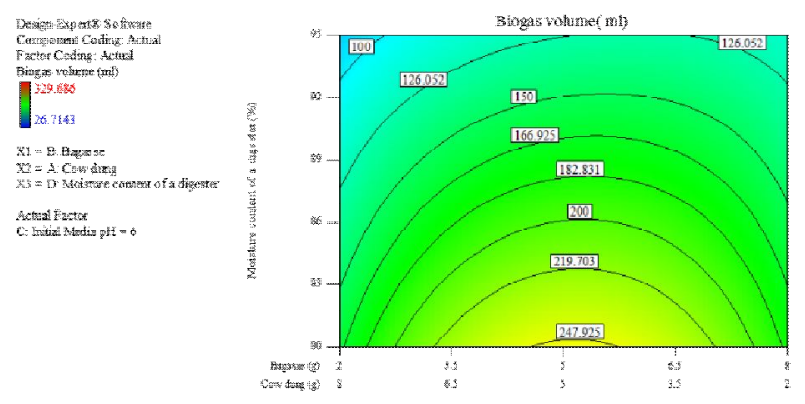

Figure 6: 2-D graphical representation of biogas volume model for cow dung and bagasse co-digestion at constant media solution $\mathrm{pH}$

Figures 6 shows that biogas volume decreases with the increase of digester moisture content at constant C: B feed ratio. It can be observed that high biogas volume can be obtained at lower digester's moisture content. Figure 6 also shows that to maintain constant biogas volume digester's moisture content should be increased at low C: Bfeed ratio and be increased at high C: B feed ratio. At low C: B feed ratio the increase in cow dung concentration favours the increase in biogas volume. At constant C: B feed ratio, biogas volume decreases as digester's moisture content increases.

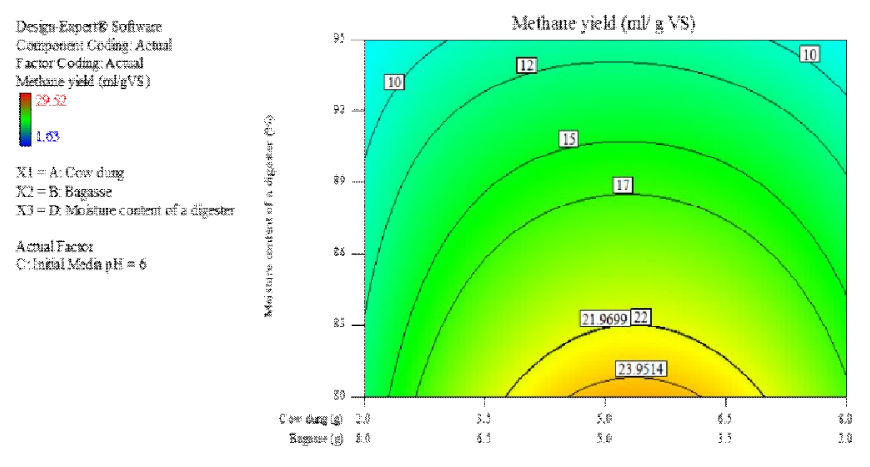

Figure 7: 2-D graphical representation of methane yield model for cow dung and bagasse co digestion at constant $\mathrm{pH}$ 
Figure 7 indicates at constant $\mathrm{C}$ : $\mathrm{B}$ feed ratio methane yield decreases as digester's moisture content increases. The highest methane yield can be obtained at lower digester's moisture content at approximately C: B feed ratio between 3.5:6.5 and 6.5:3.5. At constant digester's moisture content methane yield increases as digester's moisture content increases at low $\mathrm{C}$ : $\mathrm{B}$ feed ratio, while at $\mathrm{C}$ : $\mathrm{B}$ feed ratio above 5:5, methane yield decreases as $\mathrm{C}$ : $\mathrm{B}$ feed ratio increases.

Reactors charged with media solution with $\mathrm{pH}$ of 8.00 achieved higher biogas volume and methane yield regardless of conditions of other process variables. Media solution $\mathrm{pH}$ of 8.00 is close to the optimum $\mathrm{pH}$. Optimal $\mathrm{pH}$ for biogas production is between 6.5 and 7.8 [7, 19-22]. Lower biogas volume and methane yield production in reactors charged with media solution at $\mathrm{pH}$ of 4.00 was observed. Low $\mathrm{pH}$ media solution produces high concentration of VFAs. According to Kheireddine, et al. [19], $\mathrm{pH}$ below 6.5 produces high VFAs concentration which may cause $\mathrm{AD}$ process to slow down or fail.

Graphical analysis shows that both biogas volume and methane yield decrease as digester moisture content increases at constant C: B feed ratio. High biogas volume and methane yield are achieved at lower digester's moisture content.

\subsection{Effect of digester's moisture content on biogas volume and methane yield}

Reactors 6 and 10 were charged with equal C: B feed ratio of 2:8, equal media solution with $\mathrm{pH}$ of 8 and operated at different moisture content of $95 \%$ and $80 \%$ respectively as indicated by Table 3 . Table 3 shows that reactor 10 achieved higher biogas volume $(248.29 \mathrm{ml})$ and methane yield $19.54 \mathrm{ml} / \mathrm{gVS}$ ) compared to reactor 6 where biogas volume and methane yield of $205.86 \mathrm{ml}$ and $15.30 \mathrm{ml} / \mathrm{gVS}$ were achieved respectively. In this analysis high values of biogas volume and methane yield were achieved by reactor operated at lower moisture content of digester.

Table 3 shows that reactor 3 achieved higher biogas volume and methane yield values of $172.23 \mathrm{ml}$ and 19.57 $\mathrm{ml} / \mathrm{gVS}$ compared to reactor 4 where biogas volume and methane yield of $98.37 \mathrm{ml}$ and $8.64 \mathrm{ml} / \mathrm{gVS}$ were obtained. Reactor 3 which was operated at lower digester's moisture of $80.00 \%$ achieved higher biogas volume and methane yield compared to reactor 4 which was operated at $95.00 \%$ digester's moisture content when charged with media solution with $\mathrm{pH} 4.00$ and $\mathrm{C}$ : B feed ratio of 5:5.It was observed that reactor operated at lower digester's moisture content achieved higher values of biogas volume and methane yield.

Reactors 1 and 8 were charged with equal C: B feed ratio (5:5), equal media solution with $\mathrm{pH}$ of 8.00 and operated at different digester's moisture content of $95.00 \%$ and $80.00 \%$ respectively as presented in Table 3 . Higher biogas volume and methane yield of $329.69 \mathrm{ml}$ and $29.52 \mathrm{ml} / \mathrm{gVS}$ respectively were achieved by reactor 8 compared to reactor
1 where lower biogas volume and methane yield of 152.43 $\mathrm{ml}$ and $13.65 \mathrm{ml} / \mathrm{gVS}$ were achieved. It was noticed that low digester's moisture content operated reactor achieved higher biogas volume and methane yield.

Reactors 11 and 12 were charged with equal $\mathrm{C}$ : B feed ratio of $2: 8$, media solution with $\mathrm{pH}$ of 4 and operated at digester's moisture content of $80.00 \%$ and $95.00 \%$ respectively. Table 3 reveals that higher biogas volume and methane yield of $110.63 \mathrm{ml}$ and $6.59 \mathrm{ml} / \mathrm{gVS}$ respectively were achieved by reactor 11 compared to reactor 12 where lower biogas volume and methane yield values of $26.71 \mathrm{ml}$ and $1.63 \mathrm{ml} / \mathrm{gVS}$ were achieved respectively. This analysis reveals that a reactor operated at lower digester's moisture content achieved higher biogas volume and methane yield when charged with media solution with $\mathrm{pH}$ of 4.00 . Low cow dung concentration in a digester produces higher biogas when operated at $80.00 \%$ moisture content. High concentration of bagasse in a reactor produces higher biogas at media solution of 4.00 and digester's moisture content of $80.00 \%$.

Reactors 2 and 5 were charged with equal media solution with $\mathrm{pH}$ of $4.00, \mathrm{C}$ : B feed ratio of $8: 2$ and digester's moisture content of $80.00 \%$ and $95.00 \%$ respectively. Table 3 shows that reactor 2 which was operated at digester's moisture content of $80.00 \%$ produced higher biogas volume $(120.37 \mathrm{ml})$ and methane yield $(10.64 \mathrm{ml} / \mathrm{gVS})$ compared to reactor 5 where lower biogas volume $(73.86 \mathrm{ml})$ and methane yield $(7.77 \mathrm{ml} / \mathrm{gVS})$ were achieved. In this analysis, it was observed that low digester's moisture content charged reactors achieved higher biogas volume and methane yield. It was observed that reactor with $8.00 \mathrm{~g}$ of cow dung achieved higher biogas volume and methane yield at $80.00 \%$ digester's moisture content.

Figures 8 and 9 represent 2-D contour graphical representation of biogas volume and methane yield models respectively at digester's moisture content fixed at central point of $87.5 \%$. Figure 8 indicates as media solution $\mathrm{pH}$ increases biogas volume increases at a constant C: B feed ratio. To maintain constant biogas volume as indicated by contour line, C: B feed ratio should be increased while media solution $\mathrm{pH}$ should be decreased at $\mathrm{C}$ : $\mathrm{B}$ feed ratio of about $2: 8$ to 5:5. At C: $\mathrm{B}$ feed ratio above $5: 5$, the increase in media solution $\mathrm{pH}$ together with the increase in $\mathrm{C}$ : $\mathrm{B}$ feed ratio is required to maintain constant biogas volume.

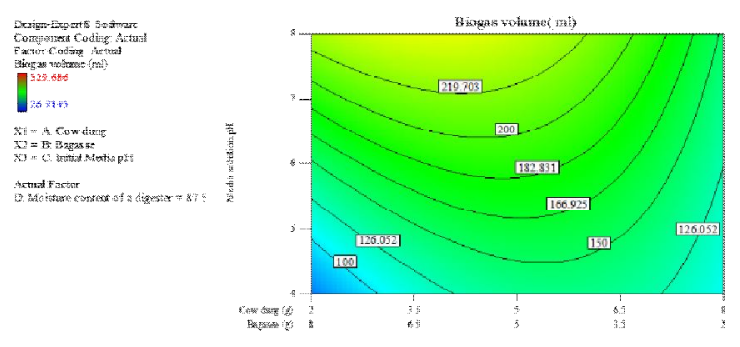

Figure 8: 2-D graphical representation of biogas volume model for cow dung and bagasse co-digestion at constant moisture content 
Figure 9 indicates as media solution $\mathrm{pH}$ increases methane increases at a constant C: B feed ratio. To maintain constant methane yield as indicated by contour line, C: B feed ratio should be increased while media solution $\mathrm{pH}$ should be decreased at C: B feed ratio of about 2:8 to 5:5. At $\mathrm{C}$ : B feed ratio above 5:5, the increase in media solution $\mathrm{pH}$ together with the increase in $\mathrm{C}$ : $\mathrm{B}$ feed ratio is required to maintain constant methane yield. The linearity of methane yield in a region of $\mathrm{C}$ : $\mathrm{B}$ feed ratio of 3.5:6.5 indicates weak interaction between media solution $\mathrm{pH}$ and $\mathrm{C}$ : $\mathrm{B}$ feed ratio of methane yield.

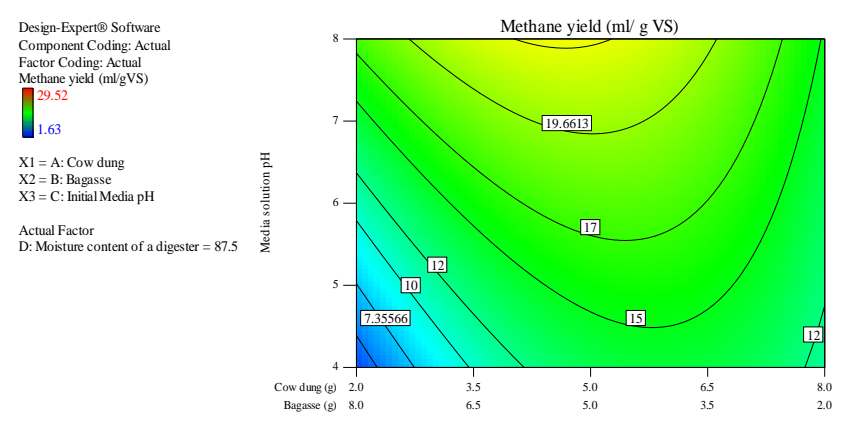

Figure 9: 2-D graphical representation of methane yield model for cow dung and bagasse co-digestion at constant moisture content

The above analyses show that low digester's moisture content $(80.00 \%)$ charged reactors achieved high biogas production than reactors which were operated at high digester's moisture content regardless of conditions of other process variables. High cow dung concentration in a reactor favoured high biogas production at media solution with $\mathrm{pH}$ of 4.00 and digester's moisture content of $80.00 \%$. High bagasse concentration in a reactor favoured high biogas production at media solution with $\mathrm{pH}$ of 4.00 and digester's moisture content of $80.00 \%$. At constant digester's moisture content and C: B feed ratio biogas volume and methane yield increase as media solution $\mathrm{pH}$ increases. It was observed that to maintain constant biogas volume and methane yield, C: B feed ratio should be increased, and media solution $\mathrm{pH}$ should be decreased at higher C: B feed ratio.

Table 3 shows that higher biogas volume of $73.86 \mathrm{ml}$ and methane yield of $7.77 \mathrm{ml} / \mathrm{gVS}$ were achieved by reactor 5 compared to reactor 12 where biogas volume and methane yield of $26.71 \mathrm{ml}$ and $1.63 \mathrm{ml} / \mathrm{gVS}$ were produced. Reactors 5 and 12 were operated at digester's moisture content $(95.00$ $\%)$ and media solution $\mathrm{pH}(4.00)$ and charged with C: B feed ratio of $8: 2$ and 2:8 respectively. In this analysis, reactor charged with high C: B feed ratio achieved high biogas volume and methane yield values.

Table 3 reveals that reactors 6 achieved higher biogas volume $(205.68 \mathrm{ml})$ and methane yield $(15.30 \mathrm{ml} / \mathrm{gVS})$ compared to reactor 9 where biogas volume and methane yield of $104.34 \mathrm{ml}$ and $9.44 \mathrm{ml} / \mathrm{gVS}$ were achieved. Reactors
6 and 9 were charged with C: B feed ratio of $2: 8$ and 8:2 respectively. Both reactors were operated at constant digester's moisture content and media solution with $\mathrm{pH}$ of 95\% and 8.00 respectively. It was noticed that reactor charged with low C: B feed ratio achieved high biogas volume and methane yield values.

Reactors 2 and 11 were charged with equal media solution $\mathrm{pH}$ (4.00), operated at moisture content of $80.00 \%$ and charged with C: B feed ratio of 8:2 and 2:8 respectively. Reactor 2 achieved higher biogas volume $(120.37 \mathrm{ml})$ and methane yield (10.64 ml/gVS) compared to lower biogas volume $(110.63 \mathrm{ml})$ and methane yield $(6.45 \mathrm{ml} / \mathrm{gVS})$ achieved by reactor 11 . It was observed that reactor charged with high feed C: B feed ratio achieved high biogas volume and methane yield.

Table 3 shows that reactors 7 and 10 were charged with C: B feed ratio of 8:2 and 2:8 respectively. Digester's moisture content and media solution $\mathrm{pH}$ were kept constant at $80.00 \%$ and 8.00 respectively. Reactor 10 achieved higher biogas volume and methane yield compared to reactor 7 where lower biogas volume and methane yield were achieved. In this analysis, it was noticed that high concentration of cow dung in the reactor achieved higher biogas production compared to reactors charged with $2.00 \mathrm{~g}$ of cow dung.

Figures 10 and 11 represent 2-D graphical representation of biogas volume and methane yield drawn at C: B feed ratio kept at central position of 5:5. Both methane yield and biogas volume counter line are straight lines and parallel, which indicates that there a weak interaction between process variables on biogas volume and methane yield at C: $\mathrm{B}$ feed ratio of 5:5 as indicated by Figures 10 and 11. Figures 10 and 11 reveal that to achieve the constant biogas volume and methane yield values at constant media solution $\mathrm{pH}$, digester's moisture content should be increased. Both graphs indicate that as media solution $\mathrm{pH}$ increases, both biogas volume and methane yield increase.

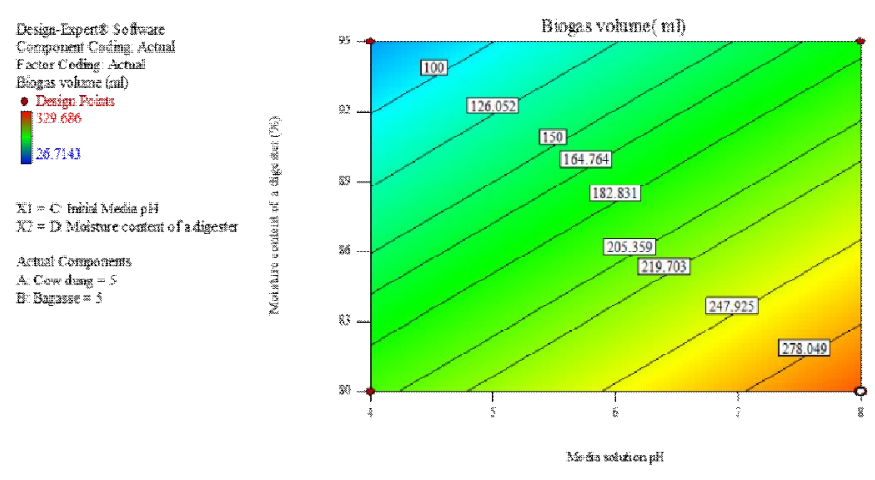

Figure 10: 2-D graphical representation of biogas volume model for cow dung and bagasse co digestion at cow dungto-bagasse feed ratio of 5:5. 


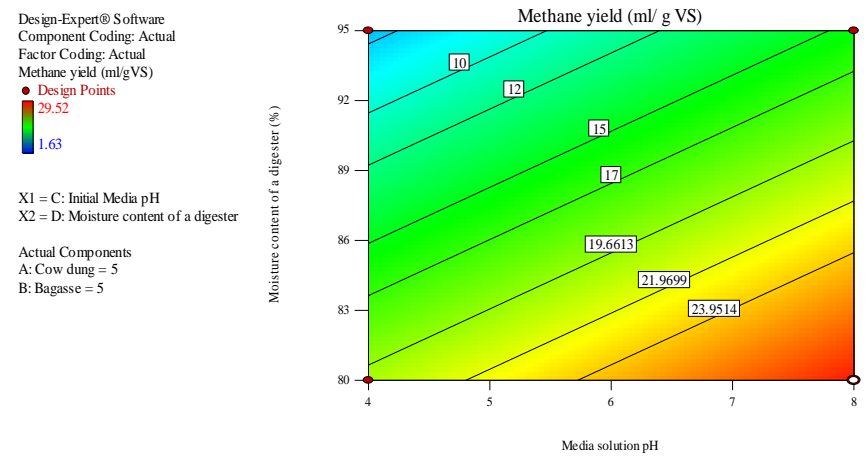

Figure 10: 2-D graphical representation of methane yield model for cow dung and bagasse co-digestion at feed ratio of $5: 5$

Reactors which were charged with high C: B feed ratio achieved higher biogas volume and methane yield when charged with media solution with $\mathrm{pH}$ of 4.00 . Reactors charged with low C: B feed ratio achieved high biogas volume and methane yield when charged with media solution with $\mathrm{pH}$ of 8.00. Graphical analysis indicates that digester's moisture content should be increased to achieve constant biogas volume and methane yield values at constant media solution pH.In conclusion, the effect of $\mathrm{C}$ : $\mathrm{B}$ feed ratio on biogas volume and methane yield depends on media solution $\mathrm{pH}$ at which $\mathrm{AD}$ process was operated.

\subsection{Optimisation}

The aim of optimisation in this work was to achieve the highest biogas volume and methane yield as indicated by optimisation goals presented by Table 6 . Optimisation results are presented in Table 7. Process condition with higher desirability was chosen as optimum condition. Table 7 indicates that a digester operated at moisture content of $80.00 \%$, media solution $\mathrm{pH}$ of $8.00,4.64$ $\mathrm{g}$ of cow dung and $5.36 \mathrm{~g}$ of bagasse are process conditions required to achieve optimum biogas volume of $305.87 \mathrm{ml}$ and methane yield and $28.75 \mathrm{ml} / \mathrm{gVS}$. Interestingly, our findings show better yield when compared to the work in [23]

Table 6: Constraints used for combined optimisation of biogas and methane yield for cow dung and bagasse digestion

\begin{tabular}{ccccc}
\hline Variable & Unit & Goal & $\begin{array}{c}\text { Lower } \\
\text { limit }\end{array}$ & $\begin{array}{c}\text { Upper } \\
\text { limit }\end{array}$ \\
Cow dung & $\mathrm{g}$ & is in range & 2.00 & 8.00 \\
Bagasse & $\mathrm{g}$ & is in range & 2.00 & 8.00 \\
Initial Media pH & & is in range & 4.00 & 8.00 \\
$\begin{array}{c}\text { Digester's } \\
\text { moisture content }\end{array}$ & $\%$ & is in range & 80.00 & 95.00 \\
Biogas volume & $\mathrm{ml}$ & maximize & 26.71 & 329.69 \\
Methane yield & $\mathrm{ml} / \mathrm{gVS}$ & maximize & 1.63 & 29.52 \\
\hline
\end{tabular}

\section{CONCLUSIONS}

- As media solution $\mathrm{pH}$ increase biogas production and methane yield increase. High cow dung concentration at any media solution $\mathrm{pH}$ favored the increase in both biogas volume and methane yield.

- High production of biogas volume and methane were favorable at high media solution $\mathrm{pH}$ (8.00). Reactors which were charged with high C: B feed ratio achieved higher biogas volume and methane yield when charged with media solution with $\mathrm{pH}$ of 4.00 . Reactors charged with low C: B feed ratio achieved high biogas volume and methane yield when charged with media solution with $\mathrm{pH}$ of 8.00 .

- Digester's moisture content of $80.00 \%$, media solution $\mathrm{pH}$ of $8.00,4.64 \mathrm{~g}$ of cow dung and $5.36 \mathrm{~g}$ of bagasse are process conditions required to achieve optimum biogas volume of $305.87 \mathrm{ml}$ and methane yield of 28.75 $\mathrm{ml} / \mathrm{gVS}$.

- Bagasse can produce biogas when co-digested with cow dung, however, the question of whether the process is sustainable is yet to be answered.

\section{REFERENCES}

[1] R. L. Holanda and F. S. Ramos, "Reuse of Waste Sugarcane Agribusiness and Green Power Generation," Journal of Clean Energy Technologies, vol. 4, 2016. https://doi.org/10.18178/JOCET.2016.4.5.309

[2] A. K. Chandel, S. S. Silvio, W. Carvalho, and O. V. Singh, "Sugarcane bagasse and leaves: foreseeable biomass of biofuel and bioproducts," Journal of Chemical technology and biotechnology, vol. 87, pp. 11-20, 2014.

[3] T. J. Rainey, "A study of the permeability and compressibility properties of bagasse pulp," Queensland University of Technology2009.

[4] K. Deepchand, "Sugar Cane Bagasse Energy Cogeneration - Lessons from Mauritius," in parliamentarian forum on energy legislation and sustainable development, Cape Town, South Africa, Cape town, 2005, p. 2005.

[5] M. L. Dotaniya, C. S. Datta, D. R. Biswas, K. C. Dotaniya, B. L. Meena, S. Rajendiran, et al., "Use of sugarcane industrial by-products for improving sugarcane productivity and soil health," Int J Recycl Org Waste Agricult vol. 5, pp. 185-194, 2016.

https://doi.org/10.1007/s40093-016-0132-8

[6] K. Krich, D. Augenstein, J. P. Batmale, J. Benemann, B. Rutledge, and D. Salour, Biomethane from Dairy Waste :A Source book for the Production and Use of Renewable Natural Gas in California, 2005.

[7] O. Prakasha, A. Kumarb, A. Pandeyc, A. Kumara, and V. Laguria, "A Review on Biogas Plant," International Journal of New Technologies in Science and Engineering, vol. 2, 2015. 
[8] A. Schnürer and A. Jarvis, "Microbiological Handbook for Biogas Plants," Swedish Waste Management pp. 1-7, 2010.

[9] P. Sosnowski, P. Wieczorek, and S. Ledakowicz, "Anaerobic co-digestion of sewage sludge and organic fraction of municipal solid wastes," Advances in Environmental Research vol. 7, pp. 609-616, 2003.

[10] B. T. Nijaguna. (2002). Biogas Technology. Available:

https://books.google.co.za/books?hl=en \&lr=\&id=Qf LDbf3qbcEC\&oi=fnd\&pg=PA112\&dq=biogas+tech nology+\&ots $=r Y 1 Z 9 \mathrm{kLw64 \& sig=u4WPIPsinBQU}$ K8JyTXcLnUDRz3U\#v=onepage\&q=biogas\%20te chnology\&f=false

[11] B. Sajeena, P. Jose, and G. Madhu, "Optimization of Process Parameters Affecting Biogas Production from Organic Fraction of Municipal Solid Waste via Anaerobic Digestion," International Journal of Environmental, Chemical, Ecological, Geological and Geophysical Engineering, vol. 8, 2014.

[12] R. Tengku, Y. Tuan, C. Hasfalina, I. Man, 1. R. Noi, and S. H. Hafid, "Optimization of Methane Gas Production From Co-Digestion of Food Waste and Poultry Manure Using Artificial Neural Network and Response Surface Methodology," Journal of Agricultural Science, vol. 6, 2014. https://doi.org/10.5539/jas.v6n7p27

[13] C. Flavin and N. Lenssen, "Beyond the petroleum age: designing a solar economy," Ekistics, pp. 342361, 1990.

[14] W. A. Telliard, "Method 1684: Total, fixed, and volatile solids in water, solids, and biosolids," US Environmental Protection Agency, Office of Water, Office of Science and Technology, Engineering and Analysis Division, Washington, DC, pp. 1-13, 2001.

[15] J. A. Cornell, Experiments with mixtures: designs, models, and the analysis of mixture data vol. 403: John Wiley \& Sons, 2011.

[16] P. Montgomety, Design and data analysis of the experiements: John Wiley and sons, 2001.

[17] M. J. Anderson and P. J. Whitcomb, "Designing experiments that combine mixture components with process factors," Chemical Engineering Progress, vol. 12, pp. 1-9, 2000.

[18] D. C. Montgomery, Design and analysis of experiments: John wiley \& sons, 2017.

[19] B. Kheireddine, K. Derbal, and M. BencheikhLehocine, "Effect of starting ph on the produced methane from dairy wastewater in thermophilic phase," Chemical Engineering Transactions,, vol. 38, pp. 511-516, 2014.

[20] N. T. Sibiya, E. Muzenda, and H. B. Tesfagiorgis, "Effect of Temperature and $\mathrm{pH}$ on The Anaerobic Digestion of Grass Silage " 2014.

[21] K. F. Adekunle and J. A. Okolie, "A Review of Biochemical Process of Anaerobic Digestion," Advances in Bioscience and Biotechnology, vol. 6, pp. 205-212, 2015. https://doi.org/10.4236/abb.2015.63020

[22] C. P. Merlin, L. R. Gopinath, and D. Divya, "A Review on Anaerobic Decomposition and Enhancement of Biogas Production through Enzymes and Microorganisms," Renewable and Sustainable Energy Reviews, pp. 167-173, 2014. https://doi.org/10.1016/j.rser.2014.03.010

[23] A.Jafari-Sejahrood, B. Najafi, S. F. Ardabili, S. Shamshirband, A. Mosavi, and Kwok-wing Chau, "Limiting factors for biogas production from cow manure: energo-environmental approach", Engineering Applications of Computational Fluid Mechanics, vol. 13, pp. 954-966. 2019. 
Malunga Sthembiso et al., International Journal of Emerging Trends in Engineering Research, 8(7), July 2020, 3898 - 3908

Table 3: Experimental results of biogas volume and methane yield for cow dung and bagasse co-digestion.

\begin{tabular}{cccccccccc}
\hline Reactor & $\begin{array}{c}\mathrm{X}_{1} \\
(\mathrm{~g})\end{array}$ & $\begin{array}{c}\mathrm{X}_{2} \\
(\mathrm{~g})\end{array}$ & $\begin{array}{c}\mathrm{Z}_{1} \\
(\mathrm{~g})\end{array}$ & $\begin{array}{c}\mathrm{Z}_{2} \\
(\%)\end{array}$ & $V S_{\text {tot }}$ & $\begin{array}{c}M_{\text {sol }} \\
(\mathrm{g})\end{array}$ & $n_{C H_{4}}$ & $\begin{array}{c}\mathrm{Y} 1 \\
(\mathrm{ml})\end{array}$ & $\begin{array}{c}\mathrm{Y} 2 \\
(\mathrm{ml} / \mathrm{gVS})\end{array}$ \\
\hline 1 & 5.00 & 5.00 & 8.00 & 95.00 & 5.81 & 141.00 & 0.52 & 152.43 & 13.65 \\
\hline 2 & 8.00 & 2.00 & 4.00 & 80.00 & 4.75 & 21.30 & 0.42 & 120.37 & 10.64 \\
\hline 3 & 5.00 & 5.00 & 4.00 & 80.00 & 5.81 & 27.75 & 0.66 & 172.23 & 19.57 \\
\hline 4 & 5.00 & 5.00 & 4.00 & 95.00 & 5.81 & 141.00 & 0.51 & 98.37 & 8.64 \\
\hline 5 & 8.00 & 2.00 & 4.00 & 95.00 & 4.75 & 115.20 & 0.50 & 73.86 & 7.77 \\
\hline 6 & 2.00 & 8.00 & 8.00 & 95.00 & 6.86 & 166.80 & 0.51 & 205.86 & 15.30 \\
\hline 7 & 8.00 & 2.00 & 8.00 & 80.00 & 4.75 & 21.30 & 0.56 & 207.43 & 24.44 \\
\hline 8 & 5.00 & 5.00 & 8.00 & 80.00 & 5.81 & 27.75 & 0.52 & 329.69 & 29.52 \\
\hline 9 & 8.00 & 2.00 & 8.00 & 95.00 & 4.75 & 115.20 & 0.43 & 104.34 & 9.44 \\
\hline 10 & 2.00 & 8.00 & 8.00 & 80.00 & 6.86 & 34.20 & 0.54 & 248.29 & 19.54 \\
\hline 11 & 2.00 & 8.00 & 4.00 & 80.00 & 6.86 & 34.20 & 0.40 & 110.63 & 6.45 \\
\hline 12 & 2.00 & 8.00 & 4.00 & 95.00 & 6.86 & 166.80 & 0.42 & 26.71 & 1.63 \\
\hline
\end{tabular}


Malunga Sthembiso et al., International Journal of Emerging Trends in Engineering Research, 8(7), July 2020,3898 - 3908

Table 7: Solutions for combined optimisation process of biogas volume and methane yield for cow dung and bagasse co-digestion

\begin{tabular}{cccccccc}
\hline $\begin{array}{c}\text { Solution } \\
\text { number }\end{array}$ & $\begin{array}{c}\text { Cow } \\
\text { dung } \\
(\mathrm{g})\end{array}$ & $\begin{array}{c}\text { Bagasse } \\
(\mathrm{g})\end{array}$ & $\begin{array}{c}\text { Media } \\
\text { solution } \\
\mathrm{pH}\end{array}$ & $\begin{array}{c}\text { Digester's } \\
\text { moisture } \\
\text { content } \\
\%\end{array}$ & $\begin{array}{c}\text { Biogas } \\
\text { volume } \\
(\mathrm{ml})\end{array}$ & $\begin{array}{c}\text { Methane } \\
\text { yield } \\
(\mathrm{ml} / \mathrm{gVS})\end{array}$ & Desirability \\
1 & 4.64 & 5.36 & 8.00 & 80.00 & 305.87 & 28.75 & 0.947 \\
2 & 4.53 & 5.47 & 8.00 & 80.00 & 306.51 & 28.66 & 0.946 \\
3 & 4.81 & 5.19 & 8.00 & 80.00 & 304.53 & 28.83 & 0.946 \\
4 & 4.43 & 5.57 & 8.00 & 80.00 & 306.88 & 28.56 & 0.945 \\
5 & 4.67 & 5.33 & 8.00 & 80.06 & 305.23 & 28.71 & 0.945 \\
6 & 4.64 & 5.36 & 7.98 & 80.00 & 305.32 & 28.70 & 0.945 \\
7 & 4.95 & 5.05 & 8.00 & 80.00 & 302.98 & 28.85 & 0.943 \\
8 & 4.78 & 5.22 & 7.96 & 80.00 & 303.83 & 28.74 & 0.943 \\
9 & 4.65 & 5.35 & 8.00 & 80.21 & 304.08 & 28.57 & 0.940 \\
10 & 4.98 & 5.02 & 7.92 & 80.00 & 300.61 & 28.68 & 0.936 \\
11 & 4.36 & 5.64 & 8.00 & 80.31 & 304.50 & 28.22 & 0.935 \\
\hline
\end{tabular}

